\title{
Coral reefs of the Pacific coast of Nicaragua
}

Received: 2 October 2009/Accepted: 6 November 2009/Published online: 21 November 2009

(C) Springer-Verlag 2009
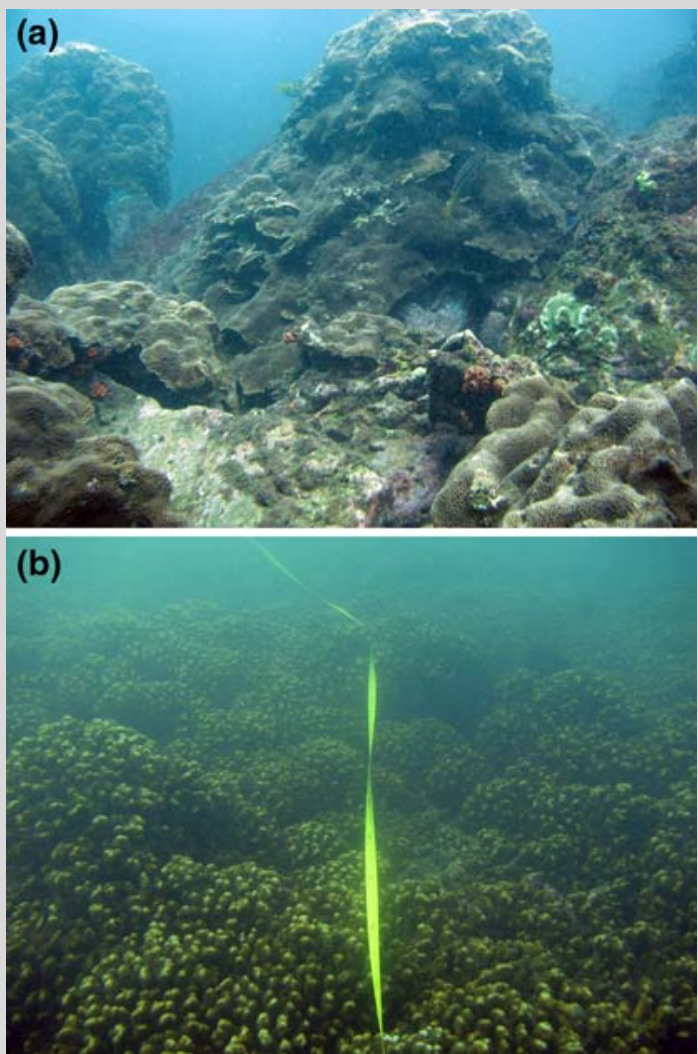

Fig. 1 a Gardineroseris planulata reef at Punta Gigante; b Pocillopora elegans reef at Punta El Toro; San Juan del Sur, Nicaragua
The coastal stretch between Guatemala and Nicaragua is known as the "Pacific Central American Faunal Gap"'. Many publications mention that there are practically no reefs or coral communities present (Durham and Barnard 1952; Glynn and Ault 2000; Spalding et al. 2001), only isolated Pocillopora colonies closer to Costa Rican (Ryan and Zapata 2003). A recent survey, conducted in July 2009 at 10 sites along the south Pacific coast of Nicaragua (Department of Rivas), a region influenced by a strong upwelling season (Pennington et al. 2006), showed the presence of abundant coral patches and actual reefs, with frameworks built mainly by Pavona gigantea, Gardineroseris planulata and Pocillopora elegans (Fig. 1). A total of 13 coral species were identified ( 9 hermatypic and 4 ahermatypic species), with a mean intersite coral cover of $9.1 \pm 6.0 \%(n=40)$. Of special interest is the area between Punta Gigante $\left(11^{\circ} 23^{\prime} \mathrm{N} 86^{\circ} 02^{\prime} \mathrm{W}\right)$ and La Anciana Rock $\left(11^{\circ} 21^{\prime} \mathrm{N}\right.$ $\left.86^{\circ} 00^{\prime} \mathrm{W}\right)$, where the highest coral cover was found. Nicaraguan reefs harbor associated species, such as the urchins Diadema mexicanum and Astropyga pulvinata, herbivorous fishes such as Stegastes spp. and carnivores such as Lutjanus argentiventris and Epinephelus labriformis.

\section{References}

Durham JW, Barnard JL (1952) Stony corals of the eastern Pacific collected by the Velero III and Velero IV. Allan Hancock Pacific Expeditions 16: $1-110$

Glynn PW, Ault JS (2000) A biogeographic analysis and review of the far eastern Pacific coral reef region. Coral Reefs 19:1-23

Pennington JT, Mahoney KL, Kuwahara VS, Kolber DD, Calienes R, Chavez FP (2006) Primary production in the eastern tropical Pacific: A review. Prog Oceanogr 69:285-317

Ryan J, Zapata Y (2003) Nicaragua's coral reefs: status, health and management strategies. In: Cortés J (ed) Latin American Coral Reefs. Elsevier, Amsterdam, pp 203-222

Spalding MD, Ravilious C, Green EP (2001) World Atlas of Coral Reefs. UNEP/WCMC and University of California Press, Berkeley

\section{J. J. Alvarado $(\bowtie) \cdot H$. Reyes-Bonilla}

Posgrado en Ciencias Marinas y Costeras, Universidad Autónoma de Baja California Sur, La Paz, Mexico e-mail: juanalva76@yahoo.com

\section{J. J. Alvarado}

Centro de Investigación en Ciencias del Mar y Limnología (CIMAR), Universidad de Costa Rica (UCR), 11501-2060 San Pedro, San José, Costa Rica

H. Reyes-Bonilla · P. A. Álvarez del Castillo Cardenas

Departamento de Biología Marina, Universidad Autónoma de Baja California Sur, La Paz, Mexico

F. Buitrago

Fondo Natura para la Conservación de la Naturaleza, Managua, Nicaragua

J. Aguirre-Rubí

Departamento de Biología, Universidad Nacional Autónoma de Nicaragua (UNAN-León) Facultad de Ciencias y Tecnología, León, Nicaragua

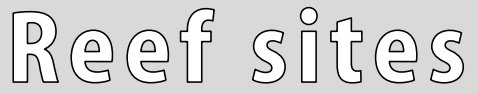

Coral Reefs (2010) 29:201 DOI $10.1007 / \mathrm{s} 00338-009-0570-0$ 